\title{
Mobile Learning: The Effective Role of Multimedia "Analytical Approach via an Object Oriented Strategy"
}

\author{
Karim Q Hussein, Ph.D \\ Computer Science Dept \\ Faculty of Science /AI- Mustansiriyah University \\ Baghdad, Iraq
}

\author{
Maha A. Al-Bayati, Ph.D \\ Computer Science Dept \\ Faculty of Science /Al- Mustansiriyah University \\ Baghdad, Iraq
}

\begin{abstract}
Mobile-Learning is an important technology in Teaching/Learning process to realize requirements of student, teacher and instructional institution. Extended applications of M-learning are wide and increasing. The current study represents an attempt to cover the analytical aspects, features and mechanism of the environment's elements in Teaching / Learning process and application via M-Learning.

The aim of this paper is to study the analytical aspects covering factors and elements of the environment of teaching/learning process via mobile, concentrating on multimedia technique role particularly $2 \mathrm{D}$ and $3 \mathrm{D}$ animation. Such classification study is presented so as to be the appropriate approach for the systematic models of designing M-Learning as well as this study could assist in framing the stages/mechanism of developing and evaluating of $\mathrm{M}$ Learning.
\end{abstract}

\section{Keywords}

Mobile, M-Learning, multimedia, animation, 2D, 3D

\section{INTRODUCTION}

WMobile-Learning (M-Learning) represents a new technology in computer applications, IT and Instructional Computer. Several researches have been undertaken to study the environment, M-Learning systems, evaluating systems , etc. But the authors did not find an integrated vision of analytical study to cover all factors, attributes, behavior and elements of M-Learning particularly the major role of multimedia technique like 2D and 3D animation technique.

The current study is created to present the needful analytical study. Thus, such integrated analytical study could open the gate for many future studies related with same domain. The current study covered most factors of the environment of MLearning. But it focused on multimedia elements.

The problem statement of this paper could be summarized in building professional table for attributes of the needful environment and behavior for each related attribute, it is the strategy of Object Oriented. Behavior regarding each attribute is considered by many elements deals with characters.

\section{LITRATURE REVIEW}

All the authors selected 5 studies related with M-learning to discuss the final conclusions and their relations with the current paper.

\subsection{Daoudi Najima \&, Ajhoun Rachida ,"} An Adaptation of E-learning standards to M-learning" : This paper presents a brief about M-Learning and its relation with e-Learning. This study considered M-
Learning as advance technology and due to the features of Mobile dynamic, it allows the student to use e-learning Modules wherever they like. Final conclusion ensured the advantages of M-Learning in active communications between users as well as the flexibility of usage in any time and place.

\subsection{Nancy E. Kiplinger," Putting the}

\section{Learning into M-Learning"}

This paper explores the challenges M-learning must meet to ensure that learners are engaged with the content. The author proposes solutions to strengthen pedagogy and a strategy for ensuring that the learning design is effective before it is deployed via technology.

The strategy is illustrated through an example of a learning package that was evaluated for effectiveness, efficiency, and acceptability. The author discusses why instructional content to be delivered via technology must be designed to be economical in scope and learner centered.

\subsection{Razieh Niazi and Qusay H. Mahmoud, "Design and Development of a Device- Independent System for Mobile Learning "}

This paper concentrated on the design and development of mobile learning systems. It presented a new applications and systems for both educators and learners to enable mobile learning. In this paper the authors present a mobile learning system which supports both educators and learners. Using this system, instructors are able to generate quizzes for various target devices. In addition, it offers learners seamless on-line as well as off-line access to the quizzes from any device.

The quiz generator in the system is part of a larger platform for mobile learning. The authors discussed the system architecture of the proposed system and the proof of concept implementation they have built using Java technologies.

\subsection{L.E. Dyson, R. Raban , A. Litchfield and E. Lawrence," Embedding Mobile Learning into Mainstream Educational Practice: Overcoming the Cost Barrier"} In this paper ,the embedding of mobile learning into mainstream educational practice is examined, that of the cost. Usage charges billed by telecommunications providers and the cost of mobile hardware are identified as the key cost barriers. However, there are also opportunities which can be leveraged to overcome the cost of implementation. The first of these is the fact that most students own a mobile phone or other mobile device. The second is provided by technological solutions such as the employment of packet technologies. The authors describe two experiments in low-cost mobile learning: 
one which uses packet technology (mobile WAP/WML) to build low-cost interactivity in the classroom, and the second which involves mobile-supported fieldwork using several cost-saving strategies.

\subsection{S. Cakula and R.Plesavnieks, "M- Learning: New Way to Access Knowledge library online"}

This paper discussed a major problem in modern technology of using e-learning and e-libraries . it is the related information systems cannot communicate with mobile devices but more and more people use different mobile devices in their real life. Paper describes a developed system which gives possibility to communicate mobile device Pocket PC with knowledge library. This connection allows different searching requests of information in knowledge library, adding new documents, downloading files and uploading information from mobile device. The final conclusion shows the system gives an innovative solution for supporting mobile device communication with knowledge data base because there has never been a specific support for mobile devices and knowledge data bases before. The system gives possibility to browse the knowledge library, download files, add new patterns and provides different types of searching and requesting. The system is available to use for free.

As a general discussion of the previous papers, they covered some practical systems, cost, e-learning and educational fundamentals related to M-learning. Also some papers suggested a professional system to present ability of communication between systems .

The authors did not find an analytical study to describe the process of M-learning deals with its environment (attributes and behavior). Thus the current paper will present such research work considering the Object Oriented strategy.

\section{OBJECTIVE OF RESEARCH}

Please This paper aims at :

Building a systematic analysis study for the environment of teaching/learning via mobile concentrating on the major role of multimedia as the powerful tool in M-learning. The needful analytical system should be built on the strategy of Object Oriented so as to realize the maximization of instructional outcome of M-Learning, meaningful learning and effective learning

\section{THE ANALYTICAL SYSTEM}

The System shown below represents the core of the work. As an Object Oriented approach , the table includes 16 rows and 5 columns.

Rows refer to the attributes of the system ( factors, elements aspects , properties, etc.) and columns represents the behavior ( mechanism) regarding each attribute through the environment of M-Learning.

The authors focused on multimedia in learning material because multimedia presents information in a way that is more interesting and easier to grasp than text alone. Animation is the core of multimedia particularly 3D animation which became a modern and updated technology for most computer application.

\begin{tabular}{|c|c|c|c|c|c|}
\hline \multirow{2}{*}{ /Factors } & \multicolumn{5}{|c|}{ Behavior aspects regarding related factors (mechanism process in M-Learning) } \\
\hline & Teacher & Student & $\begin{array}{l}\text { Expressing } \\
\text { Messages }\end{array}$ & $\begin{array}{l}\text { Multimedia2D } \\
\quad \& 3 \mathrm{D}\end{array}$ & $\begin{array}{l}\text { Multimedia Sound } \\
\quad \text { \&Images }\end{array}$ \\
\hline 1. Tutorial lessons & $\begin{array}{l}\text { Preparing the required } \\
\text { text presentation for } \\
\text { the tutorial unit with } \\
\text { the related images } \\
\text { multimedia elements. } \\
\text { Also he must prepare } \\
\text { a Q\&A for the unit } \\
\text { and the suitable } \\
\text { friendly feedback for } \\
\text { the incorrect answer } \\
\text { and powerful } \\
\text { reinforcement for the } \\
\text { correct reply. }\end{array}$ & $\begin{array}{l}\text { Read the tutorial } \\
\text { unit with related } \\
\text { multimedia, } \\
\text { considering the text } \\
\text { book and } \\
\text { references, answer } \\
\text { the question of the } \\
\text { unit, receive the } \\
\text { needful feedback. If } \\
\text { need, communicate } \\
\text { with teacher via } \\
\text { message or call. } \\
\text { Finally move to the } \\
\text { next instructional } \\
\text { task. }\end{array}$ & $\begin{array}{l}\text { The message should } \\
\text { be short, } \\
\text { concentrated on the } \\
\text { core of the concept, } \\
\text { clear language } \\
\text { suitable with the } \\
\text { student level. The } \\
\text { whole M-Learning } \\
\text { lesson period does } \\
\text { not exceed fifteen } \\
\text { minutes. Thus texts } \\
\text { must be short and } \\
\text { enhancement with } \\
\text { multimedia } \\
\text { technique. }\end{array}$ & $\begin{array}{l}\text { Images }, 2 \mathrm{D} \\
\text { animation suitable } \\
\text { for diagrams texts } \\
\text { charts flowcharts } \\
\text { flashing , lighting } \\
\text { objects. } 3 \mathrm{D} \\
\text { images, animation } \\
\text { and videos are } \\
\text { important for real } \\
\text { world objects. } \\
\text { Images present full } \\
\text { view vision. and } \\
\text { perception for the } \\
\text { instructional } \\
\text { material subject. }\end{array}$ & $\begin{array}{l}\text { Simple and clear } \\
\text { Icons, simple } \\
\text { images to represent } \\
\text { the material. } \\
\text { Images pictures } \\
\text {,cartoon and other } \\
\text { visual objects. } \\
\text { Visual multimedia } \\
\text { should express and } \\
\text { indicate to the } \\
\text { corresponding } \\
\text { meaning of the } \\
\text { desired text, } \\
\text { question and } \\
\text { dialog without } \\
\text { visual noise. About } \\
\text { sound and music } \\
\text { effects also should } \\
\text { be clear, simple } \\
\text { and don't cause } \\
\text { any audio noise to } \\
\text { the lesson. }\end{array}$ \\
\hline 2. Exercises & Short presentation of & Student & Simple, clear and & Exercises & more \\
\hline
\end{tabular}




\begin{tabular}{|c|c|c|c|c|c|}
\hline & $\begin{array}{l}\text { exercises ,guides } \\
\text { feedback and scores } \\
\text { (if any). Teacher } \\
\text { should prepare his } \\
\text { exercises considering } \\
\text { less text of submission } \\
\text { by the student. } \\
\text { Multiple choices are } \\
\text { ideal example. }\end{array}$ & $\begin{array}{l}\text { expose the required } \\
\text { solution for the } \\
\text { exercise after } \\
\text { practicing tutorial } \\
\text { lesson and real } \\
\text { class. Answers } \\
\text { could be framed by } \\
\text { simple submission. } \\
\text { Student may } \\
\text { receive immediate } \\
\text { feedback visually } \\
\text { or auditory. } \\
\text { Friendly feedback } \\
\text { of animation , } \\
\text { pictures, sound and } \\
\text { lighting objects are } \\
\text { highly recommended in } \\
\text { M-Learning. }\end{array}$ & $\begin{array}{l}\text { short exercises } \\
\text { enhanced by } \\
\text { multimedia mobile } \\
\text { technique. Mobile } \\
\text { Multimedia } \\
\text { technique must be } \\
\text { designed to present a } \\
\text { friendly meaningful } \\
\text { learning tool to the } \\
\text { student. }\end{array}$ & $\begin{array}{l}\text { their immediate } \\
\text { feedback could } \\
\text { exposed by images } \\
\text {,charts flashing , } \\
\text { animation. Some } \\
\text { selected 2D flashes } \\
\text { and video to be } \\
\text { presented and ask } \\
\text { the concern } \\
\text { question. For } \\
\text { more powerful } \\
\text { exercises } \\
\text { movies for the } \\
\text { related exercise } \\
\text { would be } \\
\text { recommended }, \\
\text { then ask the } \\
\text { desired question. }\end{array}$ & $\begin{array}{l}\text { interesting } \\
\text { environment of } \\
\text { drill and practicing } \\
\text { exercises, sound, } \\
\text { images, lighting, } \\
\text { animation, charts, } \\
\text { diagrams and } \\
\text { music are } \\
\text { considered to } \\
\text { express the drill } \\
\text { and practice lesson } \\
\text { via M-Learning. }\end{array}$ \\
\hline 3. Experiments & $\begin{array}{l}\text { Experiments are a } \\
\text { breeding ground for } \\
\text { M-lessons. Lecturer } \\
\text { should prepare the } \\
\text { experiment in the } \\
\text { laboratory and record } \\
\text { the video of HD } \\
\text { resolution and } \\
\text { enhanced with voice } \\
\text { of lecturer. Also he } \\
\text { must develop some } \\
\text { effects on the final } \\
\text { images and video of } \\
\text { the experiment, that } \\
\text { montage effects of } \\
\text { sound, music , } \\
\text { lighting text high } \\
\text { lighting is developed } \\
\text { in high quality level, } \\
\text { in order to grasp the } \\
\text { mechanism of the } \\
\text { experiment. }\end{array}$ & $\begin{array}{l}\text { Student receives } \\
\text { the experimental } \\
\text { lesson via his } \\
\text { mobile. He would } \\
\text { see, study, listen } \\
\text { and read related } \\
\text { text on the video. } \\
\text { Then he would be } \\
\text { ready to answer any } \\
\text { question deals with } \\
\text { experiment. } \\
\text { Student can express } \\
\text { some inquires } \\
\text { dialog items and } \\
\text { responses to the } \\
\text { lecturer for } \\
\text { effective interaction } \\
\text { between learner } \\
\text { and lecturer. }\end{array}$ & $\begin{array}{l}\text { Messages of } \\
\text { experiment are } \\
\text { expressed through } \\
\text { video of experiment } \\
\text { and other images , } \\
\text { charts, diagrams and } \\
\text { plans. Experiment is } \\
\text { a major part in e- } \\
\text { lessons as well as } \\
\text { training lessons. The } \\
\text { lecturer may find an } \\
\text { intelligent system } \\
\text { includes message } \\
\text { and video of } \\
\text { working process of } \\
\text { experiment. } \\
\text { It is preferred to } \\
\text { present messages in } \\
\text { experiments through } \\
\text { diagrams and graphs. }\end{array}$ & 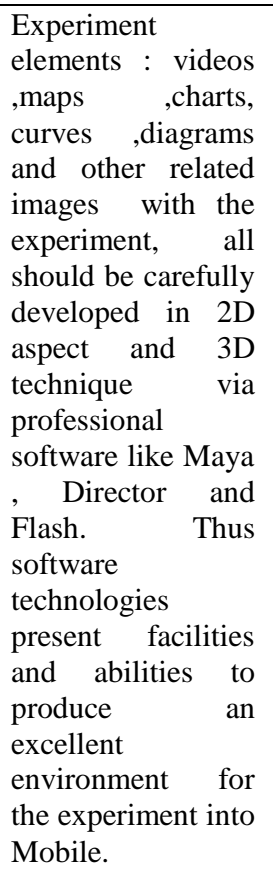 & $\begin{array}{l}\text { Effects of sound } \\
\text { and animation for } \\
\text { related experiment } \\
\text { are well considered } \\
\text { in M-learning. } \\
\text { Effects of sound } \\
\text {,colors, animation } \\
\text {,etc. of real world } \\
\text { of the experiment } \\
\text { must be simulated } \\
\text { carefully via } \\
\text { mobile lesson of } \\
\text { experiment. }\end{array}$ \\
\hline $\begin{array}{l}\text { 4. Testing and } \\
\text { Score } \\
\text { Representation } \\
\text { required) }\end{array}$ & $\begin{array}{l}\text { Teacher must prepare } \\
\text { multiple kinds and } \\
\text { amount of questions } \\
\text { with the correct } \\
\text { answer for each and } \\
\text { rate of scoring. There } \\
\text { are five major kinds : } \\
\text { multiple choices, true } \\
\text { or false, fill in blanks } \\
\text { matching between } \\
\text { two columns and } \\
\text { answer in one word. } \\
\text { Teacher should focus } \\
\text { on questions of } \\
\text { multimedia features } \\
\text { rather than text only. }\end{array}$ & $\begin{array}{l}\text { Student may } \\
\text { answer the needful } \\
\text { exam , but after } \\
\text { taking the lesson in } \\
\text { tutorial and drill } \\
\text { and practice. The } \\
\text { output of all kinds } \\
\text { of e-learning lesson } \\
\text { led to input of } \\
\text { exam lesson. } \\
\text { Student will receive } \\
\text { immediate score of } \\
\text { evaluation } \\
\text { regarding his } \\
\text { performance during } \\
\text { the exam. }\end{array}$ & $\begin{array}{l}\text { Less text and } \\
\text { mathematical details } \\
\text { of questions } \\
\text { concentrating on the } \\
\text { core of question, if } \\
\text { possible the question } \\
\text { should be enhanced } \\
\text { with multimedia } \\
\text { technique. The } \\
\text { student can receive } \\
\text { and understand the } \\
\text { question individually } \\
\text { as well as can } \\
\text { answer individually. } \\
\text { Process on } \\
\text { submission the } \\
\text { answer must be } \\
\text { simple and takes } \\
\text { little time. }\end{array}$ & $\begin{array}{l}\text { Multimedia } \\
\text { technique of } \\
\text { images and videos } \\
\text { are major part of } \\
\text { exam. Exam must } \\
\text { be expressed } \\
\text { through } \\
\text { multimedia } \\
\text { elements not only } \\
\text { text. 3D animation } \\
\text { prepares full view } \\
\text { vision to the } \\
\text { learner to exam the } \\
\text { problem and study } \\
\text { the case statement. } \\
\text { It is expected that, } \\
\text { student will answer } \\
\text { correctly after right } \\
\text { and smart study of } \\
\text { the question via }\end{array}$ & $\begin{array}{l}\text { Sound, colors } \\
\text { effects, lighting } \\
\text { effects, zooming, } \\
\text { marquee texts and } \\
\text { images, rotating } \\
\text { the objects in } 3 \\
\text { axes, cartoon } \\
\text { pictures, etc. all } \\
\text { should support the } \\
\text { student to process } \\
\text { the exam with } \\
\text { many successful } \\
\text { attempts without } \\
\text { attention and with } \\
\text { some trust in } \\
\text { himself. }\end{array}$ \\
\hline
\end{tabular}




\begin{tabular}{|c|c|c|c|c|c|}
\hline & & & & 3D movie. & \\
\hline $\begin{array}{l}\text { 5. Instructional } \\
\text { Games }\end{array}$ & $\begin{array}{l}\text { Teacher may prepare } \\
\text { the proper scenario for } \\
\text { the stages and actions } \\
\text { of game. However } \\
\text { the final goal of the } \\
\text { game is an } \\
\text { instructional goals not } \\
\text { only fun and } \\
\text { enjoyment. This kind } \\
\text { of M-Learning } \\
\text { systems is proper for } \\
\text { primary as well as } \\
\text { pre-primary schools. } \\
\text { Instructor can send } \\
\text { messages to the } \\
\text { student through his } \\
\text { progress in playing } \\
\text { the game. }\end{array}$ & $\begin{array}{l}\text { Kids must read } \\
\text { instructions of the } \\
\text { game and progress } \\
\text { of scores. Student } \\
\text { must understand } \\
\text { and feel the } \\
\text { instructional goals } \\
\text { of the game via } \\
\text { mobile. Messages, } \\
\text { scores and } \\
\text { feedback can prove } \\
\text { and ensure } \\
\text { performance of } \\
\text { learning process. }\end{array}$ & $\begin{array}{l}\text { Message of games } \\
\text { could be presented in } \\
\text { many cases , } \\
\text { instructions, moving } \\
\text { from stage to } \\
\text { another, getting rate } \\
\text { of scores, some } \\
\text { kinds of selected } \\
\text { submission, etc. } \\
\text { game and its } \\
\text { scenario depend on } \\
\text { message displayed } \\
\text { on Mobile screen. }\end{array}$ & $\begin{array}{l}\text { Multimedia is the } \\
\text { core of the game, } \\
\text { all kinds of games } \\
\text { depends mostly on } \\
\text { multimedia } \\
\text { technique. 3D } \\
\text { games represents a } \\
\text { modern aspect and } \\
\text { updated versions } \\
\text { for most game } \\
\text { applications. It is } \\
\text { highly to } \\
\text { recommended to } \\
\text { produce 3D clips } \\
\text { of games. }\end{array}$ & $\begin{array}{l}\text { Other multimedia } \\
\text { techniques are } \\
\text { considered in } \\
\text { games, graded } \\
\text { scores } \\
\text { instructions , } \\
\text { flashes, music,etc } \\
\text { must be reviewed } \\
\text { carefully. 3D } \\
\text { animation with the } \\
\text { right sound effects } \\
\text { and music as well } \\
\text { as high lighted } \\
\text { texts and colors all } \\
\text { present a prefect } \\
\text { environment of } \\
\text { instructional game } \\
\text { via mobile. }\end{array}$ \\
\hline 6.Simulation & $\begin{array}{l}\text { Simulation represents } \\
\text { advance stage of } \\
\text { learning process via } \\
\text { mobile. Teacher may } \\
\text { design the } \\
\text { mathematical model } \\
\text { of simulation } \\
\text { regarding the needful } \\
\text { real world case or } \\
\text { experiment. He must } \\
\text { also decide kind of } \\
\text { data to be submitted } \\
\text { by the learner and } \\
\text { expected out of the } \\
\text { simulation process. }\end{array}$ & $\begin{array}{l}\text { Student should be } \\
\text { qualified enough to } \\
\text { process simulation } \\
\text { instructional } \\
\text { system. His task to } \\
\text { submit the needful } \\
\text { data regarding } \\
\text { simulation subject. } \\
\text { Output expected of } \\
\text { simulation system } \\
\text { would match output } \\
\text { of real world } \\
\text { subject in the } \\
\text { similar situation. }\end{array}$ & \begin{tabular}{l}
\multicolumn{1}{c}{ simple simulation } \\
messages could be \\
acted while student \\
practices simulation \\
lesson. Students \\
needs to receive \\
continuous messages \\
to ensure his \\
learning process via \\
mobile regarding \\
that real world case \\
or experiment.
\end{tabular} & $\begin{array}{l}\text { It is better to } \\
\text { display the real } \\
\text { world case in } 3 \mathrm{D} \\
\text { animation } \\
\text { technique. Because } \\
\text { purpose r of } \\
\text { simulation is } \\
\text { simulating a real } \\
\text { world case or real } \\
\text { laboratory } \\
\text { experiment via } \\
\text { mobile screen. But } \\
\text { such kind of M- } \\
\text { Learning is } \\
\text { oriented to high } \\
\text { level of study like } \\
\text { under graduated } \\
\text { and post graduated } \\
\text { candidates. }\end{array}$ & 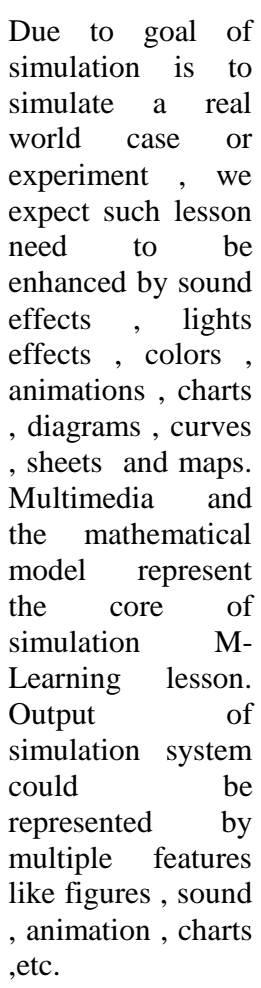 \\
\hline 7. Class level & $\begin{array}{l}\text { Teacher must prepare } \\
\text { his M- lessons to be } \\
\text { suitable with class } \\
\text { level of student and } \\
\text { skills of student in } \\
\text { both instructional } \\
\text { material , mobile } \\
\text { usage and level of } \\
\text { language presentation. }\end{array}$ & $\begin{array}{l}\text { Student should be } \\
\text { able to process } \\
\text { requirements of M- } \\
\text { Lessons } \\
\text { concentrating on } \\
\text { instructional } \\
\text { material concepts } \\
\text { and details. }\end{array}$ & $\begin{array}{l}\text { Messages should be } \\
\text { enhanced with } \\
\text { simple images and } \\
\text { cartoons particularly } \\
\text { for primary schools } \\
\text { and secondary } \\
\text { schools. }\end{array}$ & $\begin{array}{l}\text { It is important to } \\
\text { expose multimedia } \\
\text { in all levels of } \\
\text { classes. For } \\
\text { primary and } \\
\text { secondary school, } \\
\text { simple cartoon, } \\
\text { images simple and } \\
\text { clear clips 2D and } \\
\text { 3D. for } \\
\text { graduations } \\
\text { multimedia could } \\
\text { extend to wide } \\
\text { quality } \\
\text { complex features }\end{array}$ & $\begin{array}{l}\text { Sounds, visual } \\
\text { effects, music, } \\
\text { etc. all should be } \\
\text { available among } \\
\text { process of } \\
\text { teaching/learning } \\
\text { via Mobile. }\end{array}$ \\
\hline
\end{tabular}




\begin{tabular}{|c|c|c|c|c|c|}
\hline $\begin{array}{l}8 . \quad \text { Instructional } \\
\text { Computer aspects }\end{array}$ & $\begin{array}{l}\text { Teacher must select } \\
\text { proper instructional } \\
\text { computer model when } \\
\text { developing his M- } \\
\text { Learning. M-learning } \\
\text { presents kind of e- } \\
\text { learning. } \\
\text { First, analyzing the } \\
\text { instructional material } \\
\text { technical design } \\
\text { (choosing method of } \\
\text { instructional computer } \\
\text { impoftware design, } \\
\text { implementation and } \\
\text { evaluation) }\end{array}$ & $\begin{array}{l}\text { Student must take } \\
\text { the major role in } \\
\text { the } \\
\text { teaching/learning } \\
\text { process via Mobile } \\
\text { He must approve an } \\
\text { effective interaction } \\
\text { with mobile to } \\
\text { receive immediate } \\
\text { feedback. Student } \\
\text { can evaluate } \\
\text { himself while } \\
\text { learning via } \\
\text { Mobile. }\end{array}$ & $\begin{array}{l}\text { Messages between } \\
\text { mobile and student } \\
\text { should be designed } \\
\text { and framed well so } \\
\text { as the student } \\
\text { receive continuous } \\
\text { messages some } \\
\text { visually the other } \\
\text { auditory. }\end{array}$ & $\begin{array}{l}\text { Multimedia is } \\
\text { considered in } \\
\text { major elements of } \\
\text { instructional } \\
\text { computer } \\
\text { particularly in } \\
\text { training modules , } \\
\text { games, simulation } \\
\text {, experiments and } \\
\text { tutorial lessons. }\end{array}$ & $\begin{array}{l}\text { Other multimedia } \\
\text { elements are } \\
\text { essential for } \\
\text { instructional } \\
\text { computer systems. } \\
\text { Online interaction } \\
\text { via real sound of } \\
\text { instructor and } \\
\text { messages are } \\
\text { includes in the e- } \\
\text { learning modules } \\
\text { via Mobil. }\end{array}$ \\
\hline $\begin{array}{l}\text { 9. } \quad \text { supervised and } \\
\text { unsupervised learning }\end{array}$ & $\begin{array}{l}\text { Teacher must design } \\
\text { his M-Learning } \\
\text { lessons so as to be } \\
\text { unsupervised } \\
\text { candidate can use M- } \\
\text { lessons individually } \\
\text { far from the teacher. }\end{array}$ & $\begin{array}{lr}\text { Student using } & \text { M- } \\
\text { Learning should } \\
\text { prove } \\
\text { performance } \\
\text { achieving of } \\
\text { targets of lessons } \\
\text { without supervising } \\
\text { of teacher.. }\end{array}$ & $\begin{array}{l}\text { Supervised messages } \\
\text { of teacher are } \\
\text { expected. }\end{array}$ & $\begin{array}{l}\text { Multimedia } \\
\text { technique is well } \\
\text { guided } \\
\text { controlled and } \\
\text { teacher } \\
\text { presentation } \\
\text { lesson }\end{array}$ & $\begin{array}{l}\text { Some effects and } \\
\text { music , some } \\
\text { sound should be } \\
\text { expressed by } \\
\text { teacher himself. }\end{array}$ \\
\hline $\begin{array}{l}\text { 10. Feedback and } \\
\text { Reinforcement }\end{array}$ & $\begin{array}{l}\text { friendly feedback \& } \\
\text { reinforcement tools } \\
\text { like cartoons and } \\
\text { visual clips, music as } \\
\text { well as sound of the } \\
\text { teacher for more } \\
\text { interaction. }\end{array}$ & $\begin{array}{l}\text { Student must read } \\
\text { carefully feedback } \\
\text { and prepare to the } \\
\text { next rtep } \\
\text { accordingly }\end{array}$ & $\begin{array}{l}\text { Friendly feedback \& } \\
\text { reinforcement tools } \\
\text { like cartoons and } \\
\text { visual clips 3D and } \\
\text { 2D. friendly pictures } \\
\text { and clips even on } \\
\text { incorrect answer to } \\
\text { expect meaningful } \\
\text { and interesting } \\
\text { learning process. }\end{array}$ & $\begin{array}{l}\text { Multimedia frames } \\
\text { the main features } \\
\text { of any exposed } \\
\text { feedback }\end{array}$ & $\begin{array}{l}\text { Friendly feedback } \\
\& \text { reinforcement } \\
\text { tools like cartoons } \\
\text { and visual clips. } \\
\text { Such feedback } \\
\text { should encourage } \\
\text { the HI student to } \\
\text { carry on his lesson. } \\
\text { Use little words } \\
\text { which are } \\
\text { represented by } \\
\text { finger spelling. }\end{array}$ \\
\hline $\begin{array}{l}\text { 11. Virtual (Internet) } \\
\text { Communication }\end{array}$ & $\begin{array}{l}\text { Easy use of online M- } \\
\text { Learning as well as } \\
\text { flexible connection } \\
\text { between community } \\
\text { of M-Learning } \\
\text { environment ( teacher } \\
\text { student and } \\
\text { insinuation members). } \\
\text { Teacher must prepare } \\
\text { the chance to realize } \\
\text { such effective } \\
\text { connection. Facebook } \\
\text { good example for } \\
\text { virtual communication } \\
\text { between communities } \\
\text { of M-learning. }\end{array}$ & $\begin{array}{l}\text { Student } \\
\text { communicate other } \\
\text { members of M- } \\
\text { Learning } \\
\text { community ( the } \\
\text { teacher, group of } \\
\text { learners, members } \\
\text { of institution } \\
\text { members offices as } \\
\text { well as some } \\
\text { selected experts in } \\
\text { the concern topic. } \\
\text { Student can browse } \\
\text { easily and flexibly } \\
\text { to access the } \\
\text { required } \\
\text { instructional task. }\end{array}$ & $\begin{array}{lr}\text { Messages } & \text { should be } \\
\text { short, due to } \\
\text { features of M- } \\
\text { learning. Messages } \\
\text { present interaction } \\
\text { action ryeen } \\
\text { members between } \\
\text { communities. }\end{array}$ & $\begin{array}{l}\text { Text and online } \\
\text { chatting represent } \\
\text { main aspect } \\
\text { between } \\
\text { communicates. } \\
\text { Online life chatting } \\
\text { give the chance to } \\
\text { the student to } \\
\text { communicate his } \\
\text { instructor and his } \\
\text { colleagues in the } \\
\text { class. }\end{array}$ & $\begin{array}{l}\text { Real sound of } \\
\text { chatting } \\
\text { community and } \\
\text { videos are } \\
\text { important to } \\
\text { realize virtual } \\
\text { communication. }\end{array}$ \\
\hline $\begin{array}{lr}12 . \text { Mobile features } \\
\text { and } & \text { Special } \\
\text { requirements if needed }\end{array}$ & $\begin{array}{l}\text { Teacher may } \\
\text { recommend any } \\
\text { selected tools if any. }\end{array}$ & $\begin{array}{l}\text { Student must } \\
\text { prepare and } \\
\text { practice using of } \\
\text { the needful tools }\end{array}$ & $\begin{array}{lr}\text { messages } & \text { are } \\
\text { available easily } & \text { on } \\
\text { screen. } & \end{array}$ & $\begin{array}{l}\text { Clips need not for } \\
\text { special tools to be } \\
\text { displayed } \\
\text { mobile screen }\end{array}$ & $\begin{array}{l}\text { All multimedia } \\
\text { elements are } \\
\text { proper to mobile. }\end{array}$ \\
\hline $\begin{array}{l}\text { 13. Fun \& Enjoyment } \\
\text { as well as motivation }\end{array}$ & $\begin{array}{l}\text { As per modern and } \\
\text { recommended theories } \\
\text { and strategies of } \\
\text { instruction technology } \\
\text { as well as }\end{array}$ & $\begin{array}{l}\text { Student receives } \\
\text { continuous } \\
\text { feedback and } \\
\text { reinforcement in a } \\
\text { friendly method. }\end{array}$ & $\begin{array}{l}\text { Messages may } \\
\text { include elements of } \\
\text { fun \& enjoyment as } \\
\text { well motivation to } \\
\text { enhance the student }\end{array}$ & $\begin{array}{l}\text { Multimedia } \\
\text { elements provide } \\
\text { breeding ground } \\
\text { to fun, enjoyment } \\
\text { and interesting }\end{array}$ & $\begin{array}{l}\text { Sound, simple } \\
\text { icons, animated } \\
\text { images can share } \\
\text { the needful } \\
\text { environment of fun }\end{array}$ \\
\hline
\end{tabular}




\begin{tabular}{|c|c|c|c|c|c|}
\hline & $\begin{array}{l}\text { instructional computer } \\
\text { and e-Learning , all } \\
\text { ensure and prove role } \\
\text { of fun and enjoyment } \\
\text { through } \\
\text { teaching/Learning } \\
\text { process. Thus fun and } \\
\text { enjoyment should be } \\
\text { framed so as to } \\
\text { express continuous } \\
\text { fun and enjoyment } \\
\text { while receiving } \\
\text { feedback and } \\
\text { reinforcement. }\end{array}$ & $\begin{array}{l}\text { Fun and enjoyment } \\
\text { allows the } \\
\text { environment of } \\
\text { teaching/learning } \\
\text { process via Mobile } \\
\text { to be a friendly } \\
\text { tool. Student must } \\
\text { approve real } \\
\text { motivation and zeal } \\
\text { to carry out } \\
\text { learning process }\end{array}$ & $\begin{array}{l}\text { and encourage him } \\
\text { to carry out learning. }\end{array}$ & $\begin{array}{l}\text { environment of } \\
\text { teaching/learning } \\
\text { process. Funny } \\
\text { cartoon, music, } \\
\text { clips, charts } \\
\text { lighting text, some } \\
\text { 3D cuts, 2D } \\
\text { animated images, } \\
\text { etc, they all can } \\
\text { provides factors of } \\
\text { fun, enjoyment and } \\
\text { motivation to } \\
\text { learner. }\end{array}$ & $\begin{array}{l}\text { \& enjoyment. Due } \\
\text { to providing } \\
\text { environment of } \\
\text { friendly learning } \\
\text { tool } \\
\text { multimedia } \\
\text { elements, it is } \\
\text { expected to realize } \\
\text { motivation to learn } \\
\text { for student. }\end{array}$ \\
\hline 14. Economy & $\begin{array}{l}\text { Teacher may decide } \\
\text { the economy outcome } \\
\text { regarding M-learning. } \\
\text { For online learning it } \\
\text { is satisfactory because } \\
\text { student receives } \\
\text { learning material any } \\
\text { place and any time. }\end{array}$ & $\begin{array}{l}\text { Student use mobile } \\
\text { anywhere and any } \\
\text { place, so it is } \\
\text { economy }\end{array}$ & $\begin{array}{l}\text { Messages in mobile } \\
\text { are economy both in } \\
\text { cost and time. }\end{array}$ & $\begin{array}{l}\text { Mobile multimedia } \\
\text { clips, images, etc. } \\
\text { do not cost in time } \\
\text { but need technical } \\
\text { skills } \\
\text { insinuation } \\
\text { members }\end{array}$ & $\begin{array}{l}\text { Multimedia } \\
\text { elements are easy } \\
\text { to be displayed via } \\
\text { mobile and do not } \\
\text { coat in money or } \\
\text { time but need } \\
\text { professional } \\
\text { members. }\end{array}$ \\
\hline
\end{tabular}

Fig 1: The Analytical System

\section{CONCLUSION AND RECOMMONDATION}

The authors summarized conclusion of the current research as listed below:

1- This study and table of analytical environment could be considered while designing and developing M-learning systems. This study could be selected as pre-request before designing and developing M-learning modules and systems. output of this study offers the input of designing and developing M-lessons. Developers may consider all elements of environment.

2- The aspects and features of the current study are technical attributes and behavior, not only software and programming design. It is expected when considering such integrated vision for the environment, M-learning can realize meaningful learning , maximization of instructional outcomes , continuous and immediate interaction via reinforcement and feedback as well as a friendly learning tool to the learner providing fun \& enjoyment, economic tool of teaching/learning and it is modern feature of technology in teaching/learning process.

\section{REFERENCES}

[1] Al-Majali, Madallah : Evaluation Of Arabic Educational Web Sites By Experts and Specialist, A project has been submitted to the THE ARAB ACADEMY FOR BANKING AND FINANCIAL SCIENCES as part of the requirements of the MSc. Degree in Computer Science, Amman-Jordan,2004.

[2] Daoudi Najima, Ajhoun Rachida, " An Adaptation of Elearning standards to M-learning" , IMCL2008 Conference 16-18 April 2008, Amman, Jordan

[3] Dr.Mrs.Maha A .Al-Bayati, Dr.Karim Q Hussein , "Evaluating the Efficiency of the Instructional Websites "Which are Oriented to the Deaf Students" According to the Technical Criteria" , Journal of Convergence
Information Technology Volume 5, Number 2, April 2010

[4] I. Boticki1, K. Andric1 and I. Budiscak.1 , "Using mobile devices to entice the social component of learning , IMCL2008 Conference 16-18 April 2008, Amman, Jordan

[5] Karim Q Hussein , Evaluating System for E-Learning Modules for Hearing Impaired Students (Technical Criteria in Review" chapter 13, Learning-Oriented Technologies, Devices and Networks

[6] Karim Q Hussein \& Ibrahiem M. M. El Emary ," Analyzing the Various Aspects of E-Learning Modules for the Hearing Impaired Students" , Accepted International IC journal, Ulrich ISI database 2011 U.S.A

[7] L.E. Dyson , R. Raban , A. Litchfield and E. Lawrence , " Embedding Mobile Learning into Mainstream Educational Practice: Overcoming the Cost Barrier " , IMCL2008 Conference 16-18 April 2008, Amman, Jordan

[8] M. Gaeta, R. Manzo and S. Miranda ," Customized educative and training paths in a m-learning system , IMCL2008 Conference 16-18 April 2008, Amman, Jordan

[9] Nancy E. Kiplinger," Putting the Learning into MLearning", IMCL2008 Conference 16-18 April 2008, Amman, Jordan

[10] Razieh Niazi and Qusay H. Mahmoud , " Design and Development of a Device- Independent System for Mobile Learning " , IMCL2008 Conference 16-18 April 2008, Amman, Jordan

[11] S. Cakula and R.Plesavnieks" M-Learning: new way to access knowledge library online, IMCL2008 Conference 16-18 April 2008, Amman, Jordan 